\title{
Pengaruh Penambahan Lemak Kakao (Theobroma cacao L.) dan Suhu Pemanasan terhadap Karakteristik Krim Ekstrak Kunyit (Curcuma domesticate Val.)
}

\author{
The Effect of Cacao Fat (Theobroma cacao L.) and Temperature to The Characteristics of
} Turmeric Extract Cream (Curcuma domesticate Val.)

\author{
Nabila Ayu U. Cahyani, Sri Mulyani*, Ni Putu Suwariani \\ PS Teknologi Industri Pertanian, Fakultas Teknologi Pertanian, Universitas Udayana, Kampus Bukit \\ Jimbaran, Badung, Kode pos : 80361; Telp/Fax : (0361) 701801.
}

Diterima 13 Agustus 2019 / Disetujui 28 Agustus 2019

\begin{abstract}
Cream is a solid preparation in the form of an emulsion containing no less than $60 \%$ water. This study aims to determine the effect of cocoa butter substitution and process temperature on the characteristics of turmeric extract cream and determine the substitution of cocoa fat and process temperature to produce the best turmeric extract cream characteristics. This research uses factorial randomized block design. The first factor is the addition of cocoa butter which consists of 5 levels which is equal to 0g; $2.5 \mathrm{~g} ; 5 \mathrm{~g} ; 7.5 \mathrm{~g}$ and $10 \mathrm{~g}$, and the second factor is the application of heating temperature which consists of two levels, $65^{\circ} \mathrm{C}$ and $70^{\circ} \mathrm{C}$ to produce 10 treatment combinations and grouped into two groups so that 20 experimental units are obtained. The parameters observed were homogeneity, $\mathrm{pH}$, viscosity, dispersion, adhesion, separation ratio, total phenolic compounds, overall acceptance of the cream. the best treatment is determined by the effectiveness index. The results of the study stated that the treatment of cocoa butter substitution affected the $\mathrm{pH}$, viscosity, spreadability, adhesion, separation ratio, total phenolic and acceptance test of cream preference and heating temperature had an effect on total phenolic cream. Process temperature has a significant effect on total phenolic cream. The treatment of cocoa butter and heating temperature have a very significant effect on the acceptance of the cream. The treatment of substitution of cocoa fat as much as $0 \%$ at a temperature of $70^{\circ} \mathrm{C}$ heating process produces the best treatment with the following characteristics: $7800 \mathrm{cp}$ viscosity, $6.3 \mathrm{~cm}$ diameter dispersion, separation ratio $=1, \mathrm{pH} 6.40$ and total phenolic $6.95 \mathrm{mg} \mathrm{GAE} / \mathrm{g}$.
\end{abstract}

Keywords: cocoa butter, heating temperature, cream, turmeric

\footnotetext{
*Korespondensi Penulis:

Email : srimulyani@unud.ac.id
} 


\section{PENDAHULUAN}

Kosmetik adalah bahan atau sediaan yang dimaksudkan untuk digunakan pada luar tubuh manusia (epidermis, rambut, kuku, bibir dan organ genital bagian luar) atau gigi, mukosa mulut terutama untuk membersihkan, mewangikan, mengubah penampilan, memperbaiki bau badan, melindungi atau memelihara tubuh pada kondisi yang baik (Badan Pengawas Obat dan Makanan, 2013). Krim merupakan sediaan kosmetik yang paling diminati oleh masyarakat yaitu sediaan padat berupa emulsi mengandung air tidak kurang dari 60persen dan dimaksudkan untuk pemakaian luar (Ramlah, 2017). Krim diklasifikasikan sesuai formulasinya yaitu tipe M/A (minyak dalam air) dan tipe $\mathrm{A} / \mathrm{M}$ (air dalam minyak) (Rieger, 2000). Pada saat ini, tren penggunaan kosmetik khususya krim yang berbahan alami sedang meningkat, salah satu bahan alami yang dapat dijadikan krim adalah kunyit. Kunyit merupakan salah satu jenis bahan herbal yang memiliki senyawa kurkumin dan minyak atsiri yang bermanfaat dapat melembutkan, melicinkan dan menghilangkan jerawat (Latief, 2001). Emulsi akan terjadi bila di dalam bahan tersebut mengandung emulsifier dengan minyak dan air sebagai bahan bahan tedispersi dan pendispersi. Pada krim, emulsifier yang biasa digunakan adalah asam stearat. Dalam pembuatan krim, jumlah ideal penggunaan asam stearat adalah berkisar $10 \%$ (Natalie et al., 2018) dan jika lebih dari itu akan menyebabkan stabilitas krim semakin tidak stabil. Penggunaan asam stearat berlebih dalam jangka waktu yang lama dapat menyebabkan iritasi pada kulit. Sehingga dilakukan penelitian mengenai pengurangan jumlah asam stearat pada formulasi pembuatan krim. Salah satu bahan yang berpotensi menggantikan jumlah asam stearat adalah lemak kakao. Lemak kakao mengandung beberapa asam lemak diantaranya, asam palmitat $23,4 \%$, asam stearat $35,4 \%$, asam oleat $32,8 \%$, dan asam linoleat 2,1\% (Minifie, 1999). Keistimewaan dari lemak kakao adalah cepat diserap kulit karena titik leleh lemak kakao lebih rendah dari suhu tubuh manusia, yaitu $30-35^{\circ} \mathrm{C}$. Selain itu, komposisi lemak kakao juga mendekati komposisi lemak kulit sehingga aman digunakan dan tidak menimbulkan kesan berminyak setelah digunakan.

Suhu merupakan salah satu komponen penting dalam pembuatan krim.. Suhu dapat mempengaruhi tegangan antar muka pada emulsi sehingga mempengaruhi sifat fisis krim. Pada penelitian Adinata et al. (2018) diperoleh suhu optimal pada pembuatan krim ialah $65^{\circ} \mathrm{C}$. Sehingga pada penelitian ini dilakukan variasi suhu yaitu suhu $65^{\circ} \mathrm{C}$ dan $70^{\circ} \mathrm{C}$ karena emulsi pada krim masih bisa terbentuk pada suhu $70^{\circ} \mathrm{C}$ sedangkan pada suhu diatas $75^{\circ} \mathrm{C}$, karakteristik emulsi pada krim akan rusak.

Tujuan dilakukannya penelitian ini adalah untuk mengetahui pengaruh penambahan lemak kakao dan suhu pemanasan terhadap karakteristik krim ekstrak kunyit, serta mendapatkan produk krim kunyit dengan karakteristik terbaik. Harapan dari penelitian ini adalah diperolehnya produk krim dengan karakteristik terbaik.

\section{METODE PENELITIAN}

\section{Tempat dan Waktu}

Penelitian ini dilakukan di Laboratorium Biokimia dan Nutrisi serta Labortorium Analisis Pangan, Fakultas Teknologi Pertanian, Universitas Udayana. Waktu pelaksanaan penelitian dilakukan pada bulan Maret sampai Mei 2019.

\section{Bahan dan Alat}

Bahan yang digunakan untuk melakukan penelitian terdiri dari bahan baku dan bahan kimia. Bahan baku yang 
digunakan yaitu lemak kakao yang diperoleh dari UD. Harta Sari, ekstrak kunyit, propilen glikol (Emsure), gliserin (Emsure), sorbitol (Emsure), asam stearat (Emsure), setil alkohol (Merck), span 80 dan tween 80 (Emsure), virgin coconut oil (VCO) (Legenda). Bahan lain yang digunakan untuk pengujian karakteristik krim adalah, methanol (Sigma), follin ciocalteu (Merck) dan asam galat (Merck).

Peralatan yang digunakan dalam analisis adalah Viscometer (Brokfield), Centrifuge (Rotofix 32 Hettich) dan Spectrofotometer UV-VIS (Biochrome SN 133467 UV-VIS), cawan petri, mikropipet, pH-meter Beckman, Vortex, neraca analitik (Satorius) dan peralatan gelas.

\section{Rancangan Percobaan}

Rancangan percobaan ini menggunakan metode rancangan acak kelompok pola faktorial dengan dua faktor. Faktor pertama yaitu penambahan lemak kakao yang terdiri dari 5 faktor yaitu penambahan lemak kakao 0 persen, 2,5\%, $5 \%, 7,5 \%$ dam $10 \%$. Faktor kedua yaitu suhu pemanasan yang terdiri dari 2 taraf yaitu $65^{\circ} \mathrm{C}$ dan $70^{\circ} \mathrm{C}$. Berdasarkan faktor tersebut akan diperoleh 10 kombinasi perlakuan, dengan masing-masing perlakukan dikelompokkan menjadi 2 kalompok berdasarkan waktu pembuatan sehingga diperoleh 20 unit percobaan. Data yang diperoleh dianalisis keragamannya (ANOVA) dan apabila perlakuan berpengaruh maka dilanjutkan dengan uji beda nyata jujur (BNJ). Perlakuan terbaik ditentukan dengan menggunakan uji indeks efektivitas.

\section{Pelaksanaan Penelitian}

Proses pembuatan krim ekstrak kunyit dilakukan dengan beberapa tahapan. Tahap pertama yaitu mempersiapkan bahan baku yaitu ekstrak kunyit dan lemak kakao dan tahapan kedua dilakukan pembuatan krim. Pembuatan krim dilakukan dengan melakukan pencampuran. Bahan yang dicampur dibagi menjadi bahan water base dan bahan oil base. Oil base terdiri dari asam stearat, lemak kakao, setil alcohol, VCO, mineral oil, Span 80 dan ekstrak kunyit. Sedangkan bahan campuran untuk water base adalah propilen glikol, gliserin, sorbitol, Tween 80 dan aquades. Water base dan Oil base dipanaskan pada suhu $65^{\circ} \mathrm{C} \pm 2^{\circ} \mathrm{C}$ dan $70^{\circ} \mathrm{C} \pm 2^{\circ} \mathrm{C}$. setelah tersedia water base dan oil base, bahan water base dituangkan sedikit demi sedikit ke bahan oil base dan diaduk sampai terbentuk krim. Produk krim ditempatkan pada wadah plastik yang tertutup rapat, diberi etiket dan dianalisis.

\section{Variabel yang diamati}

Variabel yang diamati dalam penelitian ini adalah uji homogenitas krim (Michael dan Ash, 1997), Analisis pH, total fenolik (Sakanaka et al., 2013), daya sebar (Voight, 1994), daya lekat, viskositas (Badan Standardisasi Nasional, 1996) dan rasio pemisahan (Smoui et al., 2012).

\section{HASIL DAN PEMBAHASAN}

\section{Homogenitas Krim}

Berdasarkan hasil penelitian, krim yang dihasilkan pada setiap perlakuan homogen dan tidak memisah. Suatu sediaan krim harus homogen dan terdistribusi merata, hal ini sesuai dengan penelitian Simangunsong et al. (2018) yang menyatakan bahwa krim yang homogen menandakan semua bahan tercampur yang digunakan dalam pembuatan krim tercampur semua sehingga ketika digunakan bahan akan meresap sempurna ke kulit.

\section{Derajat keasaman krim (pH)}

Hasil analisis keragaman krim menunjukkan bahwa perlakuan penambahan lemak kakao berpengaruh nyata $(p<0,05)$ namun suhu pemanasan dan interaksi kedua perlakuan tidak berpengaruh $(\mathrm{p}>0,05)$ 
terhadap $\mathrm{pH}$ sediaan krim. Nilai rata-rata $\mathrm{pH}$

1.

krim ekstrak kunyit dapat dilihat pada Tabel

Tabel 1. Nilai rata-rata $\mathrm{pH}$ krim.

\begin{tabular}{lrrl}
\hline \multirow{2}{*}{ Perlakuan Lemak Kakao } & \multicolumn{2}{c}{ Suhu } & \multirow{2}{*}{ Rerata } \\
\cline { 2 - 3 } & $\mathrm{T} 1\left(65^{\circ} \mathrm{C}\right)$ & $\mathrm{T} 2\left(70^{\circ} \mathrm{C}\right)$ & \\
\hline P1 (Lemak Kakao 0 g) & $6,35 \pm 0,07$ & $6,40 \pm 0,00$ & $6,38 \pm 0,16 \mathrm{~b}$ \\
P2 (Lemak kakao 2,5 g) & $6,40 \pm 0,00$ & $6,40 \pm 0,07$ & $6,40 \pm 0,05 \mathrm{~b}$ \\
P3 (Lemak kakao 5 g) & $6,40 \pm 0,14$ & $6,40 \pm 0,00$ & $6,40 \pm 0,81 \mathrm{ab}$ \\
P4 (Lemak kakao 7,5 g) & $5,45 \pm 0,07$ & $6,40 \pm 0,00$ & $6,43 \pm 0,05 \mathrm{ab}$ \\
P5 (Lemak kakao 10 g) & $6,50 \pm 0,14$ & $6,70 \pm 0,14$ & $6,60 \pm 0,16 \mathrm{a}$ \\
\hline Rata-Rata & $6,42 \pm 0,09 \mathrm{a}$ & $6,45 \pm 0,14 \mathrm{a}$ & \\
\hline
\end{tabular}

Keterangan : huruf yang sama di belakang nilai rata-rata menunjukkan pengaruh yang nyata pada taraf kesalahan $5 \%$ $(\mathrm{p}<0,05)$.

Tabel 1 menunjukkan bahwa penambahan lemak kakao sebesar $10 \%$ pada suhu $70^{\circ} \mathrm{C}$ menghasilkan nilai $\mathrm{pH}$ terbesar yaitu $6,70 \pm 0,14$ sedangkan penambahan lemak kakao sebesar $0 \%$ pada suhu $65^{\circ} \mathrm{C}$ menghasilkan nilai $\mathrm{pH}$ terendah yaitu $6,35 \pm 0,07$. Tabel 1 juga menunjukkan bahwa suhu pemanasan yang digunakan tidak berpengaruh terhadap $\mathrm{pH}$ krim sehingga menghasilkan nilai $\mathrm{pH}$ yang cenderung sama pada semua perlakuan. Menurut penelitian Mitsui (1997), suhu diatas $75^{\circ} \mathrm{C}$ dapat mempengaruhi kestabilan emulsi sehingga dapat menyebabkan perubahan $\mathrm{pH}$ sedangkan pada penelitian ini, suhu maksimum yang digunakan adalah $70^{\circ} \mathrm{C}$ sehingga tidak berpengaruh pada $\mathrm{pH}$. Data yang terdapat didalam tabel 1 menunjukkan adanya kenaikan $\mathrm{pH}$ seiring dengan bertambahnya jumlah lemak kakao yang ditambahkan terhadap krim ekstrak kunyit. Peningkatan $\mathrm{pH}$ diduga disebabkan oleh $\mathrm{pH}$ lemak kakao yang lebih besar dari ekstrak kunyit yaitu 6,0 dan $\mathrm{pH}$ ekstrak kunyit yaitu 5,0 sehingga semakin banyak penambahan lemak kakao akan menyebabkan kenaikan nilai $\mathrm{pH}$. Nilai $\mathrm{pH}$ yang didapatkan pada penelitian ini masih berada pada kisaran $\mathrm{pH}$ dalam SNI 16-4399-1996 sebagai syarat mutu pelembab kulit $(4,5-8,0)$. Hal ini sejalan pula dengan penelitian Tranggono dan Latifah (2007) yang menyatakan bahwa krim yang baik digunakan pada kulit adalah krim yang memiliki $\mathrm{pH}$ yang tidak terlalu jauh dari $\mathrm{pH}$ fisiologis kulit yaitu 4,5- 6,5.

\section{Viskositas Krim}

Hasil analisis keragaman viskositas krim menunjukkan perlakuan suhu pemanasan dan perlakuan penambahan lemak kakao berpengaruh sangat nyata terhadap viskositas sediaan $\mathrm{krim}(\mathrm{p}<0,01)$. Nilai rata-rata viskositas (cp) sediaan krim dapat dilihat pada Tabel 2. Tabel 2 menunjukkan penambahan lemak kakao sebesar $0 \%$ pada suhu $70^{\circ} \mathrm{C}$ menghasilkan nilai viskositas tertinggi yaitu $7800 \pm 283 \mathrm{cp}$ sedangkan penambahan lemak kakao sebesar $10 \%$ pada suhu $65^{\circ} \mathrm{C}$ menghasilkan nilai viskositas terendah yaitu $600 \pm 141 \mathrm{cp}$.

Data pada Tabel 2 menunjukkan nilai viskositas krim yang menurun seiring dengan penambahan lemak kakao. Penurunan terjadi diduga diakibatkan oleh penambahan lemak kakao serta pengurangan asam stearat pada formulasi krim. Lemak kakao berbentuk padat pada temperatur kamar memiliki titik leleh $32-35{ }^{\circ} \mathrm{C}$ sehingga akan mencair pada suhu pemanasan $65-70{ }^{\circ} \mathrm{C}$. Asam stearat merupakan emulsifier di dalam emulsi, sehingga ketika jumlah emulsifier dikurangi, maka tegangan antarmuka emulsi akan meningkat dan menyebabkan krim menjadi lebih encer dan nilai viskositasnya menurun. 
Tabel 2 juga menunjukkan bahwa viskositas krim pada kedua suhu tidak berbeda dikarenakan suhu yang digunakan maksimal $70^{\circ} \mathrm{C}$, hal ini sesuai dengan pendapat Mitsui (1997) yang menyatakan proses emulsifikasi krim masih dapat terjadi pada suhu $70^{\circ} \mathrm{C}$ dan akan tidak stabil pada suhu diatas $75^{\circ} \mathrm{C}$. Hasil Penelitian menunjukan nilai viskositas sediaan krim pada penambahan lemak kakao sebanyak $<5 \%$ masih memenuhi SNI yaitu 2,000-7,000 cp (centipoise) (SNI 16-43991996).

Tabel 2. Nilai rata-rata viskositas krim.

\begin{tabular}{lccc}
\hline \multirow{2}{*}{ Perlakuan Lemak Kakao } & \multicolumn{2}{c}{ Suhu } & \multirow{2}{*}{ Rerata } \\
\cline { 2 - 3 } & $\mathrm{T} 1\left(65^{\circ} \mathrm{C}\right)$ & $\mathrm{T} 2\left(70{ }^{\circ} \mathrm{C}\right)$ & $6800 \pm 1178 \mathrm{a}$ \\
P1 (Lemak Kakao 0 g) & $5800 \pm 283$ & $7800 \pm 283$ & $3800 \pm 1200 \mathrm{~b}$ \\
P2 (Lemak kakao 2,5 g) & $3600 \pm 697$ & $4000 \pm 0,00$ & $2600 \pm 980 \mathrm{~b}$ \\
P3 (Lemak kakao 5 g) & $2400 \pm 0,00$ & $2800 \pm 697$ & $1200 \pm 462 \mathrm{c}$ \\
P4 (Lemak kakao 7,5 g) & $800 \pm 0,00$ & $1600 \pm 0,00$ & $800 \pm 236 \mathrm{c}$ \\
P5 (Lemak kakao 10 g) & $600 \pm 141$ & $1000 \pm 245$ & \\
\hline Rata-Rata & $2640 \pm 965 \mathrm{a}$ & $3440 \pm 1196 \mathrm{a}$ & \\
\hline
\end{tabular}

Keterangan : huruf sama yang berada di belakang nilai rata-rata menunjukkan perbedaan yang tidak nyata pada taraf kesalahan $5 \%(\mathrm{p}<0,05)$.

\section{Daya Sebar Krim}

Hasil analisis keragaman daya sebar krim menunjukkan bahwa perlakuan penambahan lemak kakao berpengaruh sangat nyata $(\mathrm{p}<0,01)$ sedangkan perlakuan suhu pemanasan beserta interaksi kedua perlakuan tidak berpengaruh nyata terhadap daya sebar sediaan krim ( $p>0,05)$. Nilai ratarata daya sebar sediaan krim dapat dilihat pada Tabel 3.

Tabel 3. Nilai rata-rata daya sebar $(\mathrm{cm})$.

\begin{tabular}{lccc}
\hline \multirow{2}{*}{ Perlakuan Lemak Kakao } & \multicolumn{2}{c}{ Suhu } & \multirow{2}{*}{ Rerata } \\
\cline { 2 - 3 } & $\mathrm{T} 1\left(65^{\circ} \mathrm{C}\right)$ & $\mathrm{T} 2\left(70{ }^{\circ} \mathrm{C}\right)$ & \\
\hline P1 (Lemak Kakao 0 g) & $6,8 \pm 0,81$ & $6,3 \pm 0,28$ & $6,55 \pm 0,21 \mathrm{a}$ \\
P2 (Lemak kakao 2,5 g) & $6,8 \pm 1,68$ & $6,6 \pm 0,64$ & $6,70 \pm 0,42 \mathrm{ab}$ \\
P3 (Lemak kakao 5 g) & $6,9 \pm 0,58$ & $6,9 \pm 0,27$ & $6,90 \pm 0,37 \mathrm{bc}$ \\
P4 (Lemak kakao 7,5 g) & $8,0 \pm 0,62$ & $8,1 \pm 0,37$ & $8,05 \pm 1,04 \mathrm{c}$ \\
P5 (Lemak kakao 10 g) & $8,6 \pm 0,01$ & $8,3 \pm 0,17$ & $8,55 \pm 0,55 \mathrm{c}$ \\
\hline Rata-Rata & $7,18 \pm 0,89 \mathrm{a}$ & $7,16 \pm 0,74 \mathrm{a}$ & \\
\hline
\end{tabular}

Keterangan: Huruf yang sama dibelakang angka menunjukkan perbedaan yang tidak nyata pada taraf kesalahan $5 \%$ $(\mathrm{p}>0,05)$.

Tabel 3 menunjukkan perlakuan penambahan lemak kakao sebesar $10 \%$ pada suhu $70^{\circ} \mathrm{C}$ menghasilkan daya sebar tertinggi yaitu $8,3 \pm 0,17 \mathrm{~cm}$ sedangkan penambahan lemak kakao $0 \%$ pada suhu $70^{\circ} \mathrm{C}$ menghasilkan daya sebar terendah yaitu $6,3 \pm 0,28 \mathrm{~cm}$. Daya sebar berbanding terbalik dengan viskositas krim sehingga semakin rendah nilai viskositas maka semakin tinggi nilai daya sebar krim, hal ini didukung oleh data viskositas pada Tabel 2 . Hal ini sesuai dengan penelitian Natalie (2017) yang menyatakan bahwa kenaikan daya sebar disebabkan oleh penurunan viskositas sehingga krim menjadi lebih encer dan daya sebar meningkat. Tidak berbeda dengan parameter $\mathrm{pH}$ dan viskositas, suhu pemanasan dalam penelitian ini tidak berpengaruh terhadap daya sebar dikarenakan suhu maksimal yang digunakan yaitu $70^{\circ} \mathrm{C}$ sehingga masih masuk dalam rentang emulsifikasi emulsi. Pada penelitian 
ini, penambahan lemak kakao $<5 \%$ masih memenuhi standar daya sebar sesuai dengan pendapat Garg et al. (2001).

\section{Daya Lekat Krim}

Berdasarkan hasil analisis keragaman daya lekat krim, hasil pengujian menunjukkan bahwa perlakuan suhu pemanasan beserta interaksinya tidak berpengaruh nyata terhadap daya lekat krim $(p>0.05)$ sedangkan perlakuan penambahan lemak kakao berpengaruh sangat nyata terhadap daya lekat krim $(\mathrm{p}<0,01)$. Nilai ratarata waktu daya lekat krim dapat dilihat pada Tabel 4.

Tabel 4. Nilai rata-rata waktu lekat (detik) sediaan krim.

\begin{tabular}{lccc}
\hline \multirow{2}{*}{ Perlakuan Lemak Kakao } & \multicolumn{2}{l}{ Suhu } & \\
\cline { 2 - 4 } & $\mathrm{T} 1\left(65^{\circ} \mathrm{C}\right)$ & $\mathrm{T} 2\left(70{ }^{\circ} \mathrm{C}\right)$ & Rerata \\
\hline P1 (Lemak Kakao 0 g) & $10,55 \pm 3,79$ & $9,78 \pm 0,65$ & $10,16 \pm 3,39 \mathrm{a}$ \\
P2 (Lemak kakao 2,5 g) & $6,55 \pm 1,69$ & $8,27 \pm 1,85$ & $7,41 \pm 1,76 \mathrm{ab}$ \\
P3 (Lemak kakao 5 g) & $4,93 \pm 0,32$ & $6,49 \pm 1,14$ & $5,71 \pm 1,13 \mathrm{abc}$ \\
P4 (Lemak kakao 7,5 g) & $3,89 \pm 1,61$ & $3,57 \pm 0,93$ & $3,73 \pm 1,08 \mathrm{bc}$ \\
P5 (Lemak kakao 10 g) & $2,42 \pm 0,22$ & $2,01 \pm 0,60$ & $2,21 \pm 0,44 \mathrm{c}$ \\
\hline Rerata & $6,02 \pm 3,60 \mathrm{a}$ & $5,63 \pm 3,15 \mathrm{a}$ & \\
\hline
\end{tabular}

Keterangan: huruf yang sama di belakang nilai rata-rata menunjukkan perbedaan yang tidak nyata pada taraf kesalahan $5 \%(\mathrm{p}>0.05)$.

Tabel 4 menunjukkan semakin banyak penambahan lemak kakao, maka daya lekat krim menurun. Penurunan daya lekat krim sejalan dengan penurunan viskositas pada Tabel 2. Daya lekat krim berbanding lurus dengan viskositas krim. Suhu pemanasan tidak berpengaruh terhadap daya lekat sediaan dikarenakan pada suhu $65-70^{\circ} \mathrm{C}$ sediaan krim masih cenderung stabil. Menurut Wasiaatmadja (1997) krim yang baik yaitu krim yang memiliki daya lekat lebih dari 4 detik sehingga efek adsorbsi zat aktif semakin besar dan penetrasi krim semakin maksimal. Pada penelitian ini, krim dengan penambahan lemak kakao maksimal
5 persen masih memenuhi standar daya lekat sesuai dengan pendapat Wasiaatmadja (1997).

\section{Rasio Pemisahan Krim}

Hasil analisis keragaman rasio pemisahan krim menunjukkan bahwa perlakuan penambahan lemak kakao berpengaruh sangat nyata $(p<0,01)$ sedangkan suhu pemanasan serta interaksi kedua perlakuan tidak berpengaruh nyata terhadap rasio pemisahan $\mathrm{krim}(\mathrm{p}>0,05)$. Nilai rata-rata rasio pemisahaan krim dapat dilihat pada Tabel 5.

Tabel 5. Nilai rata-rata rasio pemisahan sediaan krim.

\begin{tabular}{lccc}
\hline \multirow{2}{*}{ Perlakuan Lemak Kakao } & \multicolumn{3}{c}{ Suhu } \\
\cline { 2 - 4 } & $\mathrm{T} 1\left(65^{\circ} \mathrm{C}\right)$ & $\mathrm{T} 2\left(70{ }^{\circ} \mathrm{C}\right)$ & Rerata \\
\hline P1 (Lemak Kakao 0 g) & $1,00 \pm 0,000$ & $1,00 \pm 0,000$ & $1,00 \pm 0,000 \mathrm{a}$ \\
P2 (Lemak kakao 2,5 g) & $1,00 \pm 0,000$ & $1,00 \pm 0,000$ & $1,00 \pm 0,000 \mathrm{a}$ \\
P3 (Lemak kakao 5 g) & $1,00 \pm 0,000$ & $1,00 \pm 0,000$ & $1,00 \pm 0,000 \mathrm{a}$ \\
P4 (Lemak kakao 7,5 g) & $0,69 \pm 0,056$ & $0,61 \pm 0,629$ & $0,65 \pm 0,050 \mathrm{~b}$ \\
P5 (Lemak kakao 10 g) & $0,70 \pm 0,028$ & $0,65 \pm 0,028$ & $0,68 \pm 0,452 \mathrm{~b}$ \\
\hline Rerata & $0,88 \pm 0,063 \mathrm{a}$ & $0,85 \pm 0,265 \mathrm{a}$ & \\
\hline
\end{tabular}


Keterangan: huruf yang sama di belakang nilai rata-rata menunjukkan perbedaan yang tidak nyata pada taraf kesalahan $5 \%(\mathrm{p}>0.05)$.

Tabel 5 menunjukkan pemisahan hanya terjadi pada krim dengan penambahan lemak kakao diatas 7,5\%. Penambahan lemak kakao $10 \%$ suhu $65^{\circ} \mathrm{C}$ menghasilkan pemisahan tertinggi yaitu $0,70 \pm 0,028$. Pemisahan terjadi diduga akibat penambahan lemak kakao dan pengurangan asam stearat yang berfungsi sebagai emulsifier sehingga menyebabkan krim menjadi tidak stabil sehingga terjadi pemisahan. Hal ini didukung oleh data pada parameter lain yang menunjukkan bahwa semakin banyak penambahan lemak kakao maka, krim akan semakin tidak stabil. Pengujian ini ditentukan dengan cara mengamati perbandingan tinggi fase krim yang yang memisah dengan tinggi emulsi krim mula-mula. Emulsi yang baik ketika rasio pemisahannya bernilai 1 atau tidak ada yang memisah. Dalam penelitian ini, krim dengan perlakuan penambahan lemak kakao $<5 \%$ tidak mengalami pemisahan (rasio pemisahan=1).

\section{Total Fenolik Krim}

Hasil analisis keragaman total fenolik krim menyatakan bahwa perlakuan penambahan lemak kakao dan suhu pemanasan berpengaruh nyata $(p<0,05)$ sedangkan interaksi antara kedua perlakuan tidak berpengaruh nyata terhadap total fenolik krim $(p>0,05)$. Nilai rata-rata total fenolik sediaan krim disajikan dalam Tabel 6.

Tabel 6. Nilai rata-rata total fenolik (mg GAE/g) sediaan krim.

\begin{tabular}{lccc}
\hline \multirow{2}{*}{ Perlakuan Lemak Kakao } & \multicolumn{2}{c}{ Suhu } & \multirow{2}{*}{ Rerata } \\
\cline { 2 - 3 } & $\mathrm{T} 1\left(65^{\circ} \mathrm{C}\right)$ & $\mathrm{T} 2\left(70{ }^{\circ} \mathrm{C}\right)$ & \\
\hline P1 (Lemak Kakao 5 g) & $7,88 \pm 1,79$ & $6,95 \pm 0,65$ & $7,42 \pm 1,39 \mathrm{~b}$ \\
P2 (Lemak kakao 2,5 g) & $8,37 \pm 1,69$ & $7,65 \pm 1,85$ & $7,98 \pm 1,75 \mathrm{ab}$ \\
P3 (Lemak kakao 5 g) & $8,33 \pm 0,32$ & $7,64 \pm 1,14$ & $8,01 \pm 1,13 \mathrm{ab}$ \\
P4 (Lemak kakao 7,5 g) & $9,45 \pm 1,61$ & $8,38 \pm 0,93$ & $8,91 \pm 1,08 \mathrm{ab}$ \\
P5 (Lemak kakao 10 g) & $10,17 \pm 0,22$ & $9,23 \pm 0,61$ & $9,69 \pm 0,44 \mathrm{a}$ \\
\hline Rata-Rata & $8,84 \pm 1,60 \mathrm{a}$ & $7,97 \pm 1,15 \mathrm{~b}$ & \\
\hline
\end{tabular}

Keterangan: huruf yang sama di belakang nilai rata-rata menunjukkan perbedaan yang tidak nyata pada taraf kesalahan $5 \%(\mathrm{p}>0.05)$.

Tabel 6 menunjukkan krim dengan penambahan lemak kakao $10 \%$ pada suhu $65^{\circ} \mathrm{C}$ menghasilkan total fenol tertinggi yaitu $10,17 \pm 0,22 \mathrm{mg} \mathrm{GAE} / \mathrm{g}$ sedangkan $\mathrm{krim}$ dengan penambahan lemak kakao $0 \%$ suhu $70^{\circ} \mathrm{C}$ menghasilkan total fenol terendah yaitu $6,95 \pm 0,65 \mathrm{mg}$ GAE/g. Tabel 6 juga menunjukkan semakin banyak lemak kakao yang ditambahkan, maka total fenolik krim akan semakin meningkat sedangkan penambahan suhu menghasilkan penurunan total fenolik krim. Kandungan senyawa fenol pada krim berasal dari lemak kakao, hal ini didukung dengan pendapat (Misnawi, 2003) yang menyatakan bahwa senyawa utama flavonoid dalam biji kakao yaitu antosianin, leukosianidin, dan -(-)epikatekin. Katekin dalam kakao berasal dari golongan flavonoid, dimana merupakan antioksidan terkuat, dalam dark chocolate mengandung 53,5 $\mathrm{mg} / 100 \mathrm{~g}$ (Beckett, 2000) sehingga, semakin banyak lemak kakao yang ditambahkan maka total fenolik pada krim juga meningkat. Sedangkan suhu dapat menyebabkan penurunan total fenol dikarenakan suhu dapat merusak total fenolik sehingga jumlah menurun. Zapsalis (1985) menyebutkan senyawa fenol akan teroksidasi dengan adanya cahaya, panas dan oksigen. Hal tersebut terbukti dengan meningkatnya suhu maka kandungan senyawa fenol pada krim juga menurun. 


\section{Penerimaan Keseluruhan Krim}

Hasil analisis keragaman menunjukkan bahwa penambahan lemak kakao dan suhu pemanasan berpengaruh sangat nyata terhadap penerimaan keseluruhan krim $(p<0,01)$. Penerimaan keseluruhan merupakan parameter yang digunakan untuk melihat kesukaan konsumen terhadap produk. Tabel 7 menunjukkan hasil penerimaan keseluruhan yaitu penambahan lemak kakao 0 sampai dengan 5\% pada suhu $70^{\circ} \mathrm{C}$ dan penambahan lemak kakao 0 sampai dengan $2,5 \%$ pada suhu $65^{\circ} \mathrm{C}$ merupakan perlakuan yang disukai oleh panelis.

Tabel 7. Nilai rata-rata uji penerimaan keseluruhan oleh 20 panelis

\begin{tabular}{cc}
\hline Produk & Penerimaan Keseluruhan \\
\hline P1T1 (Lemak kakao $0 \mathrm{~g} ; 65^{\circ} \mathrm{C}$ ) & $5,80 \pm 1,26 \mathrm{abc}$ \\
P2T1 (Lemak kakao 2,5 g;65 ${ }^{\circ} \mathrm{C}$ ) & $5,45 \pm 1,25 \mathrm{abcd}$ \\
P3T1 (Lemak Kakao $\left.5 \mathrm{~g} ; 65^{\circ} \mathrm{C}\right)$ & $5,15 \pm 1,31 \mathrm{bcd}$ \\
P4T1 (Lemak Kakao $\left.7,5 \mathrm{~g} ; 65^{\circ} \mathrm{C}\right)$ & $5,00 \pm 1,05 \mathrm{~cd}$ \\
P5T1 (Lemak Kakao $\left.10 \mathrm{~g} ; 65^{\circ} \mathrm{C}\right)$ & $5,15 \pm 1,10 \mathrm{bcd}$ \\
P1T2 (Lemak Kakao $\left.0 \mathrm{~g} ; 70{ }^{\circ} \mathrm{C}\right)$ & $6,20 \pm 1,35 \mathrm{a}$ \\
P2T2 (Lemak Kakao 2,5g;70 $\left.{ }^{\circ} \mathrm{C}\right)$ & $5,95 \pm 1,04 \mathrm{ab}$ \\
P3T2 (Lemak Kakao $\left.5 \mathrm{~g} ; 70{ }^{\circ} \mathrm{C}\right)$ & $5,65 \pm 0,98 \mathrm{abc}$ \\
P4T2 (Lemak Kakao $\left.7,5 \mathrm{~g} ; 70^{\circ} \mathrm{C}\right)$ & $5,15 \pm 0,99 \mathrm{bcd}$ \\
P5T2 (Lemak Kakao $\left.10 \mathrm{~g} ; 70^{\circ} \mathrm{C}\right)$ & $4,65 \pm 0,95 \mathrm{~d}$ \\
\hline
\end{tabular}

Keterangan : huruf yang sama dibelakang angka menyatakan pengaruh yang sangat nyata pada taraf kesalahan $5 \%$ $(\mathrm{p}>0,05)$.

\section{Penentuan Perlakuan Terbaik}

Perlakuan terbaik ditentukan berdasarkan hasil yang menunjukkan nilai produk tertinggi. Nilai produk uji indeks efektivitas dapat dilihat pada Tabel 8. Tabel 8 menunjukkan bahwa krim dengan perlakuan terbaik yaitu pada perlakuan penambahan lemak kakao $0 \%$ dan suhu pemanasan $70^{\circ} \mathrm{C}$ (P1T2) dengan karakteristik sebagai berikut : viskositas $7800 \mathrm{cp}$, diameter daya sebar 6,3 $\mathrm{cm}$, rasio pemisahan krim $(\mathrm{F}=1), \mathrm{pH}$ 6,40, dan kandungan senyawa fenolik $6,95 \mathrm{mg}$ GAE/g, namun, pada uji organoleptik (Tabel 9) hasil statistik menunjukkan bahwa perlakuan P1T2 tidak berbeda dengan perlakuan P2T2 (lemak kakao 7,5\% suhu 70 ${ }^{\circ} \mathrm{C}$ ) dan P2T3 (lemak kakao 5\% suhu $70{ }^{\circ} \mathrm{C}$ ) sehingga penambahan lemak kakao hingga $5 \%$ pada suhu $70 \circ \mathrm{C}$ masih dapat menggantikan asam stearat.

Tabel 8. Hasil Uji Efektivitas Krim

\begin{tabular}{lc}
\hline Perlakuan & Nilai Produk \\
\hline P1T1 (Lemak Kakao 0\%;suhu $65^{\circ} \mathrm{C}$ ) & 0,73 \\
P2T1 (Lemak kakao 2,5\%;suhu $65^{\circ} \mathrm{C}$ ) & 0,73 \\
P3T1 (Lemak kakao 5\%;suhu $65^{\circ} \mathrm{C}$ ) & 0,59 \\
P4T1 (Lemak kakao 7,5\%;suhu 65 ${ }^{\circ} \mathrm{C}$ ) & 0,35 \\
P5T1 (Lemak kakao $10 \%$ suhu $65^{\circ} \mathrm{C}$ ) & 0,39 \\
P1T2 (Lemak kakao 0\%;suhu $70^{\circ} \mathrm{C}$ ) & $\mathbf{0 , 7 9}$ \\
P2T2 (Lemak kakao 2,5\%;suhu 70 $\mathrm{C}$ ) & 0,68 \\
P3T2 (Lemak kakao 5\%;suhu $\left.70^{\circ} \mathrm{C}\right)$ & 0,60 \\
P4T2 (Lemak kakao 7,5\%;suhu $70^{\circ} \mathrm{C}$ ) & 0,22 \\
P5T2 (Lemak kakao $10 \%$ suhu $70^{\circ} \mathrm{C}$ ) & 0,33 \\
\hline
\end{tabular}

Keterangan: $\mathrm{Ne}=$ nilai efektivitas; $\mathrm{Nh}=$ nilai hasil; $\mathrm{BV}=$ bobot varibel; $\mathrm{BN}=$ bobot normal 


\section{KESIMPULAN DAN SARAN}

\section{Kesimpulan}

Berdasarkan penelitian ini dapat disimpulkan sebagai berikut :

1. Perlakuan lemak kakao berpengaruh nyata terhadap pH, Daya sebar dan total fenolik serta berpengaruh sangat nyata terhadap viskositas, daya lekat dan rasio pemisahan. Suhu pemanasan, berpengaruh nyata terhadap total fenolik krim. Perlakuan lemak kakao dan suhu pemanasan berpengaruh sangat nyata terhadap uji penerimaan keseluruhan krim.

2. Perlakuan penambahan lemak kakao sebanyak $0 \%$ pada suhu proses pemanasan $70^{\circ} \mathrm{C}$ menghasilkan perlakuan terbaik dengan karakteristik sebagai berikut : viskositas $7800 \mathrm{cp}$, diameter daya sebar $6,3 \mathrm{~cm}$, rasio pemisahan $=1, \mathrm{pH} 6,40$ dan total fenolik $6,95 \mathrm{mg} \mathrm{GAE} / \mathrm{g}$.

\section{Saran}

Perlu dilakukan penelitian lebih lanjut tentang penambahan bahan aktif lainya pada krim dan bahan pengemulsi yang digunakan yang mampu menghasilkan krim dengan karakteristik krim yang lebih baik.

\section{DAFTAR PUSTAKA}

Adinata, I.G.O.H., S.Mulyani., dan G.P Ganda Putra. 2018. Pengaruh penambahan bubuk kakao (Theobroma cacao L.) dan suhu pemanasan terhadap karakteristik krim bodi scrub. Jurnal Ilmiah Teknologi Pertanian Agrotechno. 3(2):348-357.

Badan Standardisasi Nasional. 1996. Keripik pisang SNI 01-4315-1996. Jakarta: Badan Standarisasi Nasional.

Badan Pengawas Obat dan Makanan. 2013. Keputusan Kepala Badan Pengawas Obat dan Makanan Republik Tentang Kosmetik. Jakarta : Badan Pengawa
Obat dan Makanan.

Barnes, S. 2004. The importance of in vivo metabolism of polyphenols and their biological actions, phytochemicals, mechanism of action. CRC Press.

Hii, C.L., C.L. Law, S. Suzannah, Misnawi and M. Cloke. 2009. Polyphenols in cocoa (theobroma cacao l.). Asian Journal of Food and Agro-Industry 2 (4) : 702- 722.

Michael and Ash, I., 1997. A formulary of cosmetic preparation. Chemical Publishing Co, New York 222-223.

Minifie. 1999. Chocolate, Cocoa, and Conventionary, Science and Technology. AVI. Westport. Connecticut.

Montesqrit \& Ovianti, R. (2013). Pengaruh suhu dan lama penyimpanan terhadap stabilitas minyak ikan dan mikrokapsul minyak ikan . Jurnal Peternakan Indonesia 62-68.

Mulato, S., S. Widyautomo, Misnawi, E. Suharyanto. 2005. Pengolahan Produk Primer dan Sekunder Kakao. Balai Pusat Penelitian Kopi dan Kakao : Jember.

Natalie, A., S.Mulyani., B.Admadi,H. 2017. Hubungan lama simpan dengan karakteristik mutu pada berbagai formulasi krim ekstrak kunyit (Curcuma dosmeticate Val). Jurnal Rekayasa dan Manajemen Agroindustri $5: 21-30$.

Othman, A., A.M.M. Jalil, K.K. Wang, A. Ismail, N.A. Ghani and I. Adenan. 2010. Epicatechin content and antioxidant capacity of cocoa beans from four different countries. African Journal of Biotechnology 9 (7) : 10521059 .

Ramlah, S. 2017. Karakteristik mutu efek 
penambahan polifenol pada hand body lotion berbasis lemak kakao terhadap kulit. Jurnal Industri Hasil Perkebunan. 12 29. File://C:users/ACERPC/Downloads/34 73-10842-1-PB\%20(3).pdf. Diakses pada 19 Desember 2018.

Rieger, M. 2000. Harry's cosmeticology. Ed ke 8. New York. Chemical Publishing co Inc.

Sakanaka, S, Tachibana, Y., Okad, Yuki. 2005. Preparation and antioxidant properties of extract of japanese persimo leaf (kakinocha-cha). Food Chemistry. $89: 569-575$.

Schmitt, W.H., 1996, Skin Care Products, in Williams, D.F. and Schmitt, W.H. (Eds.), Cosmetics And Toiletries Industry, 2 nd Ed., Blackie Academy and Profesional, London.

Simangunsong, F.M.P., S.Mulyani., A.Hartiati. 2018. Evaluasi karakteristik krim ekstrak kunyit (Curcuma domesticate val.) pada berbagai formulasi. Jurnal Rekayasa dan Manajemen Agroindustri 6 (1): 11-21.
Smaoui, S, Hilma, H.B., Jarraya, R., Kamoun, N.G., Ellouze, R., Damak, M. 2012. Cosmetic emulsion of virgin coconut oil : formulasi and bio-physical evaluation. African Journal of Biotechnology 11(40): 9664-9671.

Tranggono, R.,L., dan F. Latifah. 2007. Buku Pegangan Ilmu Pengetahuan Kosmetik. Gramedia Pustaka Utama, Jakarta.

Voight, T. 1994. Buku Pelajaran Teknologi Farmasi Edisi V. Ahli Bahasa Noerono s. Universitas Gadjah Mada Press: Yogyakarta.

Wahyuni., A. Lullung., D.W Asriyati. 2016. Formulasi dan peningkatan mutu masker wajah dari biji kakao non fermentasi dengan penambahan rumput laut. Jurnal Industri Perkebunan 1(1): $89-94$. 